Vol 1 No 22020 Desember 2020

Jurnal AlphaEuclidEdu

Received: 21/10/2020; Revised: 19/11/2020; Accepted: 02/12/2020

\title{
KEMAMPUAN MENYELESAIKAN SOAL PISA PADA KONTEN CHANGE AND RELATIONSHIP
}

\author{
${ }^{1}$ Teresa, Helyana, ${ }^{2}$ Zubaidah, ${ }^{3}$ Nursangaji, Asep \\ ${ }_{1,2,3}$ Pendidikan Matematika FKIP Universitas Tanjungpura Pontianak \\ Email: helyanateresa61@gmail.com,
}

\begin{abstract}
This Educators are required to be able to form a generation that can act effectively in the face of world changes that are so fast and complex. The PISA study that has been conducted has not used a sample that depicts all Indonesian students. Especially for students who are in SMP Negeri 4 Jawai not yet become a sample in the PISA study. This study aims to describe and find out how the ability to solve the Program for International Student Assessment (PISA) content on change and relationship content by junior high school students. The research method used in this research is descriptive qualitative research survey. Subjects in this study were 26 subjects. The results of the discussion showed that the ability to solve PISA questions for students was said to be still very low. This is because students have not been able to understand the problem correctly, students have not been able to identify and select relevant information because mathematical models in context are available, students have difficulty in giving arguments at every step of solving problems and drawing conclusions.
\end{abstract}

Keyword: Change and Relationship, Menyelesaikan Soal, PISA

\section{Pendahuluan}

Menurut Heppel, dkk (2004) Pendidik diharap dapat mendoktrin generasi yang cakap bekerja selaku efisien untuk menyongsong peralihan global yang sedemikian kompleks dan cepat. Pendidikan pada dasarnya merupakan satu diantara cara untuk menumbuhkembangkan kapasitas peserta didik yaitu melalui cara menggerakkan dan menyediakan kegiatan suatu kegiatan belajar mengajar kepada mereka (Hamidy, 2016). The partnership for 21st century skills menyatakan pembelajaran harus focus mengelaborasikan 4C sebagai kompetensi untuk mengembari ranah abad 21 yaitu communication, critical thinking, creativity, and collaboration. Matematika merupakan satu diantara pelajaran yang sanggup mencapai kriteria tersebut di sekolah.

OECD (2013) mengungkapkan bahwa matematika bagian penting bagi remaja dalam menyambut rumor dan persoalan baik di cangkupan aktivitas keseharian, masyarakat, pekerjaan. Sepemikiran dengan hal ini visi pembelajaran matematika di sekolah yang dikembangkan NCTM (2000: 5) yang dapat diartikan sebagai berikut "Pada dunia yang terus menerus mengalami perubahan ini, mereka yang dapat memahami dan mahir bermatematika mempunyai peluang atau opsi yang meningkat secara tajam untuk merancang masa depan mereka. Kompetensi matematika memelopori batu loncatan menuju masa depan yang inventif. Kompetensi matematika yang kurang menyebabkan pintu-pintu itu tertutup." Sehingga kompetensi matematika berpengaruh untuk aktivitas keseharian perlu untuk peningkatankan sebagai satu diantara evaluasi untuk merancukan kearifan pendidikan pada abad 21.

Guru diharapkan dapat mengintensifkan siswa memecahkan soal demi keterampilan berpendapat perseptif, rasional, terorganisasi dan tertata dan menguasai konsep untuk 
penataran matematika. Ujian Nasional (UN) saat ini masih sebagai salah satu parameter kesuksesan anak didik pada tujuan pembelajaran matematika. Lembaga internasional yang berkecimpung di dalam sektor pendidikan sebagai takaran bagaimana kemampuan matematika siswa di Indonesia dengan negara lain di dunia, diantaranya adalah menyertai ujian Programme for International Student Assessment (PISA).

Peran serta Negara Indonesia tatkala partisipasi menyertai ujian yang diadakan oleh juga PISA framework 2012 menjelaskan bahwa kerangka soal PISA matematika memiliki tiga perspektif antara lain: (1) isi (content), (2) situasi (context), dan (3) kelompok kompetensi (competency cluster). Soal PISA diperbanyak berpedoman pada empat konten matematika, yaitu: Uncertainty and Data, Space and Shape, Quantity, dan Change and Relationships. PISA memperlihatkan bahwa pada umumnya skor performa literasi matematika di Negara Indonesia pada tahun 2009 peringkat 61 dari 65, pada tahun 2012 peringkat 64 dari 65, dan pada tahun 2015 Indonesia peringkat 63 dari 70 negara peserta (OECD). Kemampuan siswa Indonesia dalam menyelesaikan soal PISA sangat kurang dipandang dari peringkat pada ujian yang tertera.

Wahyuni (2011) menyebutkan kenyataan mengindikasikankan bahwa satu di antara kesusahan yang timbul pada siswa di pembelajaran matematika ialah mengerjakan soal. Kesusahanya bukan hanya pada soal kesusahan, tapi juga kesusahan pada model matematika yang mempunyai arti terkait dengan satu soal. Kemampuan menyelesaikan soal bisa dipandang sebagai satu diantara dari proses dan hasil belajar. Menurut Kirkley (2003) menyelesaikan soal mengecap proses berpikir tingkat tinggi seperti proses penggambaran, afiliasi, abstraksi, manipulasi, penalaran, penjabaran, paduan, dan menyamaratakan yang masing-masing dikelola secara terkoordinasi.

Berdasar perjelasan tersebut dapat ditarik kesimpulan bahwa Negara Indonesia masih berada di bawah standar pada umunya dalam hal kompetensi internasional. Peserta didik di Negara Indonesia masih belum dapat mengatasi persoalan matematis dalam keseharian. Hal tersebut didasarkan pada soal yang belum tersedia untuk menimbang kecakapan menyelesaikan soal matematika peserta didik serupa soal nonrutin model PISA. Bersumber pada pengalaman PPL di sekolah guru belum mampu menangkap atau menguasai bahkan tidak mengetahui perkara soal model PISA. Sehingga soal yang dibagikan pada peserta didik berupa soal rutin.

Mengenai yang akan jadi ruang cangkupan dalam penelitian ini yaitu kemampuan menyelesaikan soal PISA pada muatan relationship and change, tujuan pengambilan muatan relationship and change pada penelitian ini karena materi aljabar merupakan materi yang masih dianggap sulit bagi anak didik. Fakta tersebut dapat dilihat pada hasil riset PISA yang memperlihatkan peserta didik yang bisa mengerjakan soal dengan tepat pada geometri sejumlah $47,5 \%$, bilangan $53,7 \%$ dan statistic $61,9 \%$. Hanya $41,4 \%$ siswa yang menjawab benar pada soal aljabar. Siswa ditekankan untuk sanggup membuat model matematika, merampungkan model dan menguraikan penyelesaian yang diperoleh, dan memahami soal sehingga kemampuan pemecahan soal matematis di Indonesia disebutkan bisa untuk menyelesaikan soal bertaraf internasional satu diantaranya soal yang diujikan PISA. 
Vol 1 No 22020 Desember 2020

Jurnal AlphaEuclidEdu

Studi PISA yang telah dilakukan belum menggunakan sampel yang menggambarkan seluruh siswa Indonesia. Terutama untuk siswa yang ada di SMP Negeri 4 Jawai belum menjadi sampel dalam studi PISA. Karena peneliti penasaran bagaimana kemampuan mengerjakan soal PISA untuk konten change and relationship oleh siswa SMP Negeri 4 Jawai. Maksud dalam riset ini ialah mendeskripsikan kemahiran mengerjakan soal PISA dalam muatan relationship and change oleh siswa sekolah menengah pertama.

Menyelesaikan soal bisa dilihat sebagai rekayasa informasi secara runtut, tahap demi tahap dengan mengolah informasi yang dibutuhkan melalui pandangan untuk mencapai suatu hasil pemikiran sebagai respon terhadap persoalan yang dihadang (Nasution, 2006: 7). Menyelesaikan soal ialah prosedur mengaplikasikan pengetahuan yang telah didapat sebelumnya ke dalam kondisi baru yang belum diketahui. Karakter pada soal atau tugas yang didalamnya berbentuk menyelesaikan soal adalah: (1) ada tantangan pada materi latihan dan (2) soal tidak mungkin diselesaikan menggunakan prosedur yang telah diketahui oleh penjawab (Wardhani, 2010: 40). Soedjadi (2000: 36) mengungkapkan bahwa kemampuan menyelesaian soal ialah suatu kapabilitas pada peserta didik agar bisa memakai tindakan matematis untuk menyelesaikan soal pada matematika, persoalan ilmu lainya dan dalam keseharian.

Berdasarkan sejumlah pengertian menyelesaikan soal tersebut diatas, dapat disebutkan bahwa Menyelesaikan soal ialah upaya jelas pada bentuk mengetahui lintasan keluar atau gagasan berbarengan dengan destinasi yang hendak dicapai. Menyelesaikan soal merupakan suatu prosedur yang kompleks mengupayakan perorangan untuk menyingkronkan kemahiran, kepandaian, interpretasi, dan naluri seraya rangka menyanggupi desakan dari suatu situasi.

Menurut Suherman (2001: 93) menyelesaikan soal adalah komponen terpenting dari kurikulum matematika karena pada tahapan pembelajaran maupun menyelesaikannya, peserta didik diharapkan mendapatkan profesionalisme memakai pengetahuan juga kecakapan yang telah didapatkan untuk diaplikasikan pada menyelesaikan soal yang bersifat tidak rutin. Keterampilan matematika yang esensial mengimplementasikan aturan dalam soal tidak rutin, menemukan pola, penyamarataan, korespondensi matematika sehingga dapat berkembang dengan lebih efektif.

Seraya adanya impresi prinsip belajar kognitif, sehingga terjalin motifikasi ideologi terhadap arti menyelesaikan soal yang membidik pada kesibukan mental bersifat kompleks menyeluruhi berbagai kefasihan dan aktivitas psikologis. Garofalo dan Lester (2003), menyebutkan menyelesaikan soal meliputi proses berpikir tingkat tinggi seperti proses pencitraan, federasi, resume, muslihat, berpikit logis, penyelidikan, paduan dan generalisasi yang sendirinya penting ditata secara terkoordinasi.

Wu (2010) menyatakan OECD adalah organisasi antar pemerintah negara yang memiliki ketertatikan pada keputusan kebijakan sebagai tujuan utama. Dalam penelitian ini focus adalah untuk mengetahui kompetensi sains, membaca dan matematika, anak umur 15 tahun (Ahyan, dkk. 2014). Masing-masing potensi yang diriset dari PISA ialah kemampuan sangat krusial untuk kesibukan bangsa setelah pendidikan formal. 
Pusztai dan Bacskai (2015) menyatakan untuk mengevaluasi kemampuan pelajar saat mengaplikasikan kecakapan dan kepandaian pada situasi lingkungan pekerjaan dan menyuguhkan buatan kualitas karakter yang bisa dikomparasi bersama kawasan lainnya ialah tujuan PISA. PISA bersama dengan pelajaran matematika memiliki tujuan yang sama yaitu menyampaikan keterangan tentang kesanggupan anak didik untuk mengimplementasikan matematika pada beragam kondisi Wijaya (2014). Sehingga, penelitian PISA pada lingkungan kemampuan matematika memiliki tujuan memperkirakan kemampuan anak didik untuk menggunakan konsep matematika saat menyelesaiakan permasalahan keseharian.

Konteks PISA dalam matematika menyampaikan penjelasan dan alasan saat melakukan suatu penilaian yakni bagaimana peserta didik berusia 15 tahun menggarap persoalan yang bersifat matematis baik ketika berhadapan dengan persoalan yang mengemuka didunia nyata atau secara keseluruhan suatu evaluasi tentang bagaimana peserta didik usia 15 tahun yang mempunyai kemahiran literasi matematis. Untuk menggambarkan secara spesifik tentang permasalahan tersebut, pada (OECD, 2010:90) terdapat beberapa unsur yang mesti dibedakan: (1) Situasi atau konteks duduk persoalan; (2) Konten matematika dimanfaatkan untuk menyelesaikan persoalan yang terhimpun oleh inspirasi terpilih selaku keseluruhan, dimana persoalan tersebut terhubung dengan matematika yang akan dipecahkan bermunculan; (3) Kompetensi matematika mesti digiatkan untuk dapat terjaring dengan dunia nyata.

Proses matematisasi berhubungan dengan permodelan matematika, yang mana proses dimulai lewat kejadian dunia nyata, diakhiri dengan penyelesaian yang sesuai beserta fakta yang ada dan melewati beberapa tingkatan. Proses matematisasi dalam literasi matematika terbagi menjadi tiga tahapan utama untuk menyelesaikan soal matematika, yaitu formulate, interpret dan employ.

Tahap "formulate" menunjukkan pada kepiawaian pribadi untuk mengingat, mengidentifikasi peluang saat mengaplikasikan matematika dan menampilkan pola matematika terhadap persoalan kontekstual yang dihadapan. Selanjutnya proses "interpret" melihat kompetensi perorangan untuk merefleksikan penyelesaian, hasil dan simpulan matematika juga menginterprestasikannya kedalam persoalan di keseharian. Proses "employ" menyatakan pada kompetensi perorangan pada menggunakan fakta, konsep, penalaran dan tahapan matematika untuk mengakhiri masalah yang sudah dirumuskan sehingga memdapatkan pemecahan matematis. (Edo, Hartono, \& Putri, 2013).

\section{Metode Penelitian}

Bentuk penelitian yang berperankan pada penelitian ini adalah penelitian kualitatif. Menurut subana dan sudrajat (2011: 17), penelitian kualitatif merupakan penelitian yang bersifat deskriptif karena data yang diulas berupa deskripsi dari indikasi yang terlihat, yang tak mesti selalu berbentuk angka-angka atau koefisien antar variable. Berdasarkan masalah pada penelitian ini, bentuk penelitian yang sesuai adalah studi survey. Penelitian survey pada lumrahnya dilakukan untuk mencapai suatu generalisasi dari 
peninjauan yang tidak komprehensif (Sugiyono, 2011). Kerlinger dalam Sugiyono (2011) mengungkapkan bahwa penelitian survey bisa dilakukan pada komunitas kecil maupun besar, tetapi data yang dipelajari adalah data dari sampel yang diambil dari populasi tersebut. Subjek dalam penelitian ini adalah semua siswa kelas IX B SMP Negeri 4 Jawai yang telah mempelajari materi Aljabar. Alat penghimpunan data pada penelitian ini adalah verifikasi kemampuan menyelesaikan soal PISA, dan wawancara. Tahapan penelitian ini terdiri dari tiga tahapan yang dipaparkan sebagai berikut.

Tahap Persiapan

Tahapan yang dilaksanakan dalam tahap ini yaitu: (1) Melangsungkan observasi di SMP Negeri 4 Jawai; (2) Mengurus surat permohonan izin penelitian kepada ketua Prodi Pendidikan Matematika FKIP Untan; (3) Menyusun dan melakukan perbaikan proposal penelitian sesuai hasil seminar; (4) Menyusun instrument berupa enam buah soal tes tertulis; (5) Melakukan validasi instrument. Instrument yang di validasi adalah soal tes tertulis dan pedoman wawancara; (6) Merevisi soal yang sudah divalidasi baik isi maupun bahasa yang digunakan jika itu diperlukan; (7) Melaksnakan uji coba soal ke sekolah yang lain; (8) Memproses data hasil uji coba instrument.

Tahap Pelaksanaan

Tahapan yang dilakukan pada tahap ini yaitu: (1) Menentukan kelas yang akan menjadi subjek penelitian serta jadwal penelitian yang akan dilaksanakan; (2) Membagikan soal tes tertulis sebanyak 6 buah terkait kemampuan menyelesaikan soal PISA dengan konten change and relationship kepada subjek; (3) Mengoreksi hasil jawaban siswa sesuai dengan indikator yang telah ditetapkan; (4) Melakukan wawancara kepada subjek penelitian; (5) Mengklasifikasi seluruh data dari lapangan berupa tes tertulis dan transkip wawancara; (6) Menafsirkan dan membahas hasil analisis data; (7) Menarik kesimpulan dari dari hasil laporan; (8) Mengurus surat bukti telah melakukan penelitian pada tanggal 17 Oktober 2019 dari kepala SMP Negeri 4 Jawai.

Tahapan Akhir

Tahapan yang dilaksanakan pada tahap ini yaitu; Menggambarkan/mendeskripsikan hasil dari pengolahan data dan kemudian dianalisis data sebagai jawaban dari rumusan masalah yang diajukan dalam penelitian ini serta menyimpulkan hasil akhirnya; (2) Mengurutkan data hasil olahan ke dalam bentuk laporan penelitian.

\section{Hasil Penelitian dan Pembahasan}

\subsection{Hasil Penelitian}

Untuk memaparkan kemampuan menyelesaikan persoalan anak didik berdasar empat indikator, berpegang pada hasil penelitian yang telah dilaksanakan, sehingga didapatkanlah data yang dibutuhkan untuk menggapi rumusan masalah penelitian ini yakni merencanakan masalah, memahami soal tes, melangsungkan rencana penyelesaian dan mengoreksi kembali pada soal PISA konten change and relationship oleh anak didik SMPN4 Jawai. Pada bagian ini akan dijabarkan terkait hasil penelitian, 
pembahasan dan keterbatasan peneliti. Adapun tujuan dalam penelitian ini yakni untuk mendeskripsikan kemampuan menyelesaikan soal PISA pada konten change and relationship oleh siswa kelas IX B SMP N 4 Jawai. Sebanyak 26 anak didik kelas IX B SMP Negeri 4 Jawai menjadi subjek dalam penelitian ini yang telah mempelajari materi aljabar, dengan jumlah soal ada 6 soal essay. Tiap soal memiliki skor maksimal 16 dengan rentang skor 0 - 4 untuk tiap indicator menyelesaikan soal.

Tabel 1: Hasil Penskoran Kemampuan Menyelesaikan Soal PISA Konten Change and Relationship Siswa Kelas IX B SMP Negeri 4 Jawai Tahun Ajaran 2019/2020

\begin{tabular}{|c|c|c|c|c|c|c|c|c|}
\hline \multirow{2}{*}{ No. } & \multirow{2}{*}{ Nama } & \multicolumn{6}{|c|}{ Skor Tiap Soal } & \multirow{2}{*}{ Jumlah } \\
\hline & & 1 & 2 & 3 & 4 & 5 & 6 & \\
\hline & Jumlah Skor & 58 & 83 & 117 & 337 & 126 & 114 & 835 \\
\hline & Skor Maksimum & 416 & 416 & 416 & 416 & 416 & 416 & 2496 \\
\hline & Rata-rata Skor & 2.23 & 3.19 & 4.50 & 12.96 & 4.85 & 4.38 & 32.12 \\
\hline & Ketercapaian \% & 13.94 & 19.95 & 28.13 & 81.01 & 30.29 & 27.40 & 33.45 \\
\hline
\end{tabular}

Berdasarkan tabel 1. menggambarkan hasil tes kemampuan menyelesaikan persoalan PISA pada konten change and relationship siswa dengan persentase ketercapaian $33,45 \%$

\subsection{Pembahasan}

Dalam penelitian ini peneliti mempunyai 4 indikator soal PISA konten change and relationshiop yaitu mempersiapkan penyelesaian, memahami permasalahan, melakukan pemecahan, dan mengecek ulang. Sebanyak 6 soal dipakai pada penelitian ini. Dalam penelitian ini yang akan dibahas ialah kemampuan mengerjakan soal PISA konten change and relationship. (1) Memahami soal adalah satu diantara parameter kemampuan menyelesaikan soal metematika anak didik yang dibutuhkan saat menyelesaikan soal PISA. Tahap pada memahami soal antar lain membatasi informasi dari soal, menetapkan informasi penting, serta mengambil strategi yang tepat saat menyelesaikan soal. Dalam mengartikan informasi dalam masalah anak didik diharapkan bisa mengatakan informasi yang akan digunakan pada strategi penyelesaian. (2) Merencanakan menyelesaikan soal adalah tindakan dimana anak didik menimbang kembali informasi yang sangat penting dan menuliskan informasi apasaja yang terkait, mecari urutan atau pola pemecahan, dan memformulasikan berdasarkan pengetahuan yang sebelumnya anak didik dapat melalui tahapan pembelajaran. (3) Melaksanakan penyelesaian pada bagian penyelesaian ini adalah langkah dimana anak didik bisa menyelesaikan soal dan memperoleh jawaban yang tepat dan benar. (4) Memeriksa ulang. Tahap memeriksa ulang hasil adalah langkah akhir dari pendekatan kemampuan menyelesaikan soal matematis siswa. Hal tersebut perlu dilaksanakan saat ingin mengetahui hasil apa yang didapat telah tepat dengan syarat dan tidak timbul kesenjangan antara pertanyaan dengan jawaban.

Soal kemampuan menyelesaikan soal PISA terdiri dari enam soal essai dan dibagikan pada anak didik kelas IX. Peneliti tidak mengalami hambatan dan penelitian 
berlangsung sangat lancar karena pada saat membagikan soal kemampuan menyelesaikan soal PISA konten change and relationship pada anak didik kelas IX hadir semua. Eksemplar pengerjaan penyelesaian soal yang dibuat dalam penelitian ini berbentuk soal matematika PISA berbentuk soal cerita pada konten change and relationship atau pada materi aljabar. Hambatan yang dialami anak didik ialah karena mereka tidak benar-benar memahami materi yang ditanyakan pada setiap soal berdasar penunjuk menyelesaikan soal yang subjek penelitian alami berbeda partikularnya saat menyelesaikan soal cerita.

Jika dirincikan untuk soal nomor 1 terdapat 23 subjek yang mengerjakan soal seperti gambar 4.1 dan hanya ada 3 subjek yang menuliskan apasaja yang diketahui dan ditanyakan dan menyelesaikan soal dengan langkah penyelesaian yang benar dari soal tesebut. Dikaji dari jawaban subjek, bahwa mereka mengalami kesulitan saat memisalkan sisi dari persegi dan tidak mengingat rumus untuk mencari luas persegi dan keliling persegi. Walaupun rumus luas persegi benar, tapi rumus kelilingnya salah dan ini yang menyebabkan mereka keliru dalam menyelesaikan soal tersebut. Mereka juga tidak melakukan pemeriksaan kembali untuk memastikan jawaban mereka benar atau tidaknya dengan tidak menuliskan kesimpulan dalam jawaban mereka.

Untuk Soal nomor 2 terdapat terdapat 2 subjek yang mengerjakan seperti pada gamabar 4.2, ada 9 subjek menuliskan diketahui tapi tidak menuliskan apa yang ditanyakan dalam soal dan 15 subjek lainnya mengerjakan dengan cara yang sama yaitu langsung mengalikan nilai yang diketahui pada soal tanpa mengidentifikasi soal terlebih dahulu untuk mengetahui apa yang diperlukan untuk menjawab pertanyaan soal tersebut. Dapat dilihat dari jawaban subjek, bahwa 15 subjek yang lain tidak memahami soal sehingga langsung mengerjakan soal seperti mengalikan nilai yang ada pada soal dan tidak menuliskan apa yang ditanyakan dan diajwab, dan mereka juga tidak memeriksa kembali jawaban mereka untuk mengetahui kebenarannya dengan tidak menuliskan kesimpulan pada jawaban mereka.

Untuk soal nomor 3, terdapat 11 subjek mengerjakannya seperti pada gambar 4.3, ada 4 subjek mengerjakan mengerjakan sama hanya saja salah perhitungan, hal ini terjadi mungkin subjek kurang memperhatikan jawaban dan tidak melakukan pemeriksaan kembali terhadap soal ini, dan ada 11 subjek lainnya menjawab tidak cocok dengan apa yang terdapat pada soal. Ini dikarenakan siswa tidak memahami yang dimaksudkan pada soal tersebut, ialah apa diketahui dan ditanyakan pada soal tersebut sehingga mereka tidak bisa menyelesaikan masalah pada soal dan mereka juga tidak memeriksa kembali jawaban mereka dengan tidak menuliskan kesimpulan di jawaban mereka.

Pada soal nomor 4, terdapat 17 peseta didik mengerjakan dengan benar diantarananya ada 2 subjek mengerjakan seperti pada gambar 4.4, ada 15 subjek mengerjakan degan memisalkan untuk persegi enam nilainya 5 dan persegi nilainya 2 , jadi mereka mendapatkan untuk menara pertama memiliki tinggi $21 \mathrm{~m}$, menara kedua $19 \mathrm{~m}$ dan untuk menara ketiga yang dicari mereka mendapatkan tinggi $9 \mathrm{~m}$. karena mereka menambahkan tingi persegi enam dengan persegi sesuai banyak tingkatan yang 
ada pada gambar soal. Ada 2 subjek tidak menuliskan kesimpulan dari soal, dan ada 8 subjek yang mengerjakan dengan tidak menuliskan diketahi dan ditanya, ada yang salah dalam menghitung dan ada yang hanya menuliskan jawabannya saja, tidak menuliskan langkah pengerjaan dari soal tersebut dan tidak memeriksa kembali dengan menuliskan kesimpulan pada jawaban mereka. Dari penjelasan subjek sudah memahami soal, sehingga banyak subjek yang bisa menjawab soal ini.

Untuk soal nomor 5, terdapat 3 subjek mengerjakan seperti gambar 4.5 hanya saja satu subjek lainnya menegerjakan dengan menuliskan kesimpulan dari jawaban tersebut, dan 23 subjek lainnya mengerjakan dengan cara yang berbeda yaitu mereka menuliskan rumus yang diketahui pada soal hanya saja subjek tidak memahami mana yang harus dimasukkan untuk kerumus untuk menyelesaikan permasalah soal nomor 5. Pada lebar jawab, sebagian subjek menuliskanrumus yang ada pada soal dan menuliskan kesimpulan hanya saja jawaban yang dihasilkan dari penyelesaian soal ini belum tepat, subjek belum terlalu memahami permasalahan yang ada pada soal, dan tidak memeriksa kembali jawaban mereka dengan tidak menuliskan kesimpulan pada jawaban mereka.

Untuk soal terakhir yaitu soal nomor 6 terdapat 25 subjek yangmengerjakan hampir sama dengan gambar 4.6 dan hanya 1 subjek yang mengerjakan soal dengan jawaban yang hampir yang hampir benar. Pada soal ini, dari 25 subjek ada dari beberapa yang menuliskan diketahui hanya saja subjek tidak memahami soal dengan baik, ada yang menuliskan rumus yang akan digunakan, subjek juga menuliskan kesimpulan yang artinya mereka melakukan pemeriksaan kembali dari jawaban tersebut.

Berdasar pembahasan diatas bisa disimpul bahwa kemampuan menyelesaikan soal anak didik kelas IX B SMP Negeri 4 jawai masih dikatakan sangat rendah, karena masih banyak siswa yang belum medapat memenuhi kriteria menyelesaikan soal.

\section{Kesimpulan}

Berdasarkan hasil analisis data dan pembahasan yang telah dilakukan, diperoleh kesimpulan bahwa kemampuan menyelesaikan soal PISA konten change and relationship di SMP Negeri 4 Jawai masih sangat jauh tertinggal. Terlihat dari persentase rata-rata skor peserta didik yakni 33,45\%. Kemampuan anak didik pada saat menyelesaikan persoalan PISA konten change and relationship adalah sebagai berikut: (1) Anak didik tidak dapat memahami persoalan dengan tepat. (2) Anak didik tidak dapat mengenali dan memilih informasi yang relevan. (3) Anak didik tidak bisa menciptakan model matematika berdasarkan informasi yang ada dan membuat prediksi terhadap informasi yang relevan karena model matematika pada kondisi yang tersedia. (4) Anak didik kesukaran untuk menyatakan argument disetiap tahap menyelesaikan dan kesimpulan yang dibuat.

\section{Referensi}

Ahyan, S., dkk. 2014. Developing mathematics problems based on pisa level. IndoMS Journal Mathematics Education, 5(1), 47-56.

Hamidy, A. 2016. Kemampuan Siswa SMP Kalimantan Timur Dalam Menyelesaikan Soal Matematika Model PISA dan TIMSS. Proposal: Pascasarjana UNY. 
Vol 1 No 22020 Desember 2020

Jurnal AlphaEuclidEdu

Heppel, S., dkk. 2004. 21st century school: learning environments of the future. London: CABE \& RIBA.

Nasution, S. 2006. Metode Penelitian Naturalistik Kualitatif. Bandung: Tarsito

NCTM. 2000. Principles and Standards for School Mathematics. USA: the National Council of Teacher Mathematics inc.

OECD. 2013. PISA 2012 assessment and analytical framework: mathematics, reading, science, problem solving and financial literacy. Paris: OECD Publishing.

Pusztai, G dan Bacskai, K. 2015. Parochial schools and pisa effectiveness in three central european countries. Social Analysis, 5, 145-161.

Subana dan Sudrajat. 2011. Dasar-dasar Penelitian Ilmiah. Bandung: Pustaka Setia.

Sugiyono, 2011. Metode Penelitian Kuantitatif, Kualitatif dan R\&D. bandung: Alfabeta.

Suherman, Erman. 2001. Strategi Pembelajaran Matematika Kontemporer. Bandung: JICA-UPI

Wardhani, Sri. 2010. Pembelajaran Kemampuan Pemecahan Masalah Matematika di SMP. Yogyakarta: PPPPTK

Wijaya, A., Heuvel-Panhuizen, M. V., Doorman, M. et al. 2014. Difficulties in solving context-based PISA mathematics tasks: an analysis of students' errors. The Mathematics Enthusiast, 11, 555-584.

$\mathrm{Wu}, \mathrm{M} .2010$. Comparing the similarities and differences of PISA 2003 and TIMSS, OECD Education Working Papers, 32, OECD Publishing. http://dx.doi.org/10.1787/5km4psnm13nx-en 